\title{
Correction to: Formaldehyde formation in the glycine cleavage system and its use for an aldolase-based biosynthesis of 1,3- propanediol
}

Yingying $X u^{1}$, Hao Meng ${ }^{1}$, Jie Ren ${ }^{2}$ and An-Ping Zeng ${ }^{1,3^{*}}$

\section{Correction to: J Biol Eng 14, 15 (2020) \\ https://doi.org/10.1186/s13036-020-00237-2}

Following the publication of the original article [1], the authors became aware of a typographical error in the title: '1,3-propanediol' was inadvertently spelled as ' 1,3 prodanediol'. This has now been corrected in the title of both the original article as well as this Correction.

\begin{abstract}
Author details
${ }^{1}$ Beijing Advanced Innovation Center for Soft Matter Science and Engineering, Beijing University of Chemical Technology, North Third Ring Road 15, Chaoyang District, Beijing 100029, China. ${ }^{2}$ State Key Laboratory for Biology of Plant Diseases and Insect Pests/Key Laboratory of Control of Biological Hazard Factors (Plant Origin) for Agri-product Quality and Safety, Ministry of Agriculture, Institute of Plant Protection, Chinese Academy of Agricultural Sciences, Beijing 100081, China. Institute of Bioprocess and Biosystems Engineering, Hamburg University of Technology, Denickestrasse 15, 21073 Hamburg, Germany.
\end{abstract}

Published online: 07 December 2020

\section{Reference}

1. Xu, et al. Formaldehyde formation in the glycine cleavage system and its use for an aldolase-based biosynthesis of 1,3-propanediol. J Biol Eng. 2020 14:15. https://doi.org/10.1186/s13036-020-00237-2.

\footnotetext{
The original article can be found online at https://doi.org/10.1186/s13036020-00237-2

* Correspondence: aze@tuhh.de

${ }^{1}$ Beijing Advanced Innovation Center for Soft Matter Science and

Engineering, Beijing University of Chemical Technology, North Third Ring Road 15, Chaoyang District, Beijing 100029, China

${ }^{3}$ Institute of Bioprocess and Biosystems Engineering, Hamburg University of Technology, Denickestrasse 15, 21073 Hamburg, Germany
}

(c) The Author(s). 2020 Open Access This article is licensed under a Creative Commons Attribution 4.0 International License which permits use, sharing, adaptation, distribution and reproduction in any medium or format, as long as you give appropriate credit to the original author(s) and the source, provide a link to the Creative Commons licence, and indicate if changes were made. The images or other third party material in this article are included in the article's Creative Commons licence, unless indicated otherwise in a credit line to the material. If material is not included in the article's Creative Commons licence and your intended use is not permitted by statutory regulation or exceeds the permitted use, you will need to obtain permission directly from the copyright holder. To view a copy of this licence, visit http://creativecommons.org/licenses/by/4.0/. The Creative Commons Public Domain Dedication waiver (http://creativecommons.org/publicdomain/zero/1.0/) applies to the data made available in this article, unless otherwise stated in a credit line to the data. 